\title{
Nota
}

\section{SOIL AGGREGATION, ORGANIC CARBON CONCENTRATION, AND SOIL BULK DENSITY AS AFFECTED BY COVER CROP SPECIES IN A NO-TILLAGE SYSTEM}

\author{
Adriano Stephan Nascente ${ }^{(1) *}$, Yuncong Li(2) $^{(2)}$ and Carlos Alexandre Costa Crusciol(3)
}

\footnotetext{
(1) Empresa Brasileira de Pesquisa Agropecuária, Centro Nacional de Pesquisa em Arroz e Feijão, Santo Antônio de Goiás, Goiás, Brasil.

(2) University of Florida, Soil and Water Science Department, Tropical Research and Education Center, Homestead, State of Florida, USA.

(3) Universidade Estadual de São Paulo, Departamento de Produção Vegetal, Botucatu, São Paulo, Brasil.

* Corresponding author.

E-mail: adriano.nascente@embrapa.br
}

\begin{abstract}
Soil aggregation and the distribution of total organic carbon (TOC) may be affected by soil tillage and cover crops. The objective of this study was to determine the effects of crop rotation with cover crops on soil aggregation, TOC concentration in the soil aggregate fractions, and soil bulk density under a no-tillage system (NTS) and conventional tillage system (CTS, one plowing and two disking). This was a three-year study with cover crop/rice/cover crop/rice rotations in the Brazilian Cerrado. A randomized block experimental design with six treatments and three replications was used. The cover crops (treatments) were: fallow, Panicum maximum, Brachiaria ruziziensis, Brachiaria brizantha, and millet (Pennisetum glaucum). An additional treatment, fallow plus CTS, was included as a control. Soil samples were collected at the depths of 0.00-0.05 $\mathrm{m}, 0.05-0.10 \mathrm{~m}$, and $0.10-0.20 \mathrm{~m}$ after the second rice harvest. The treatments under the NTS led to greater stability in the soil aggregates (ranging from 86.33 to $95.37 \%$ ) than fallow plus CTS (ranging from 74.62 to $85.94 \%$ ). Fallow plus CTS showed the highest number of aggregates smaller than $2 \mathrm{~mm}$. The cover crops affected soil bulk density differently, and the millet treatment in the NTS had the lowest values. The cover crops without incorporation provided the greatest accumulation of TOC in the soil surface layers. The TOC concentration was positively correlated with the aggregate stability index in all layers and negatively correlated with bulk density in the $\mathbf{0 . 0 0 - 0 . 1 0 ~} \mathrm{m}$ layer.
\end{abstract}

Keywords: Brachiaria brizantha, Brachiaria ruziziensis, no-tillage system, Panicum maximum, Pennisetum glaucum, soil management. 


\title{
RESUMO: AGREGAÇÃO DO SOLO, CONCENTRAÇÃO DE CARBONO ORGÂNICO E DENSIDADE DO SOLO EM RAZÃO DE ESPÉCIES DE PLANTAS DE COBERTURA NO SISTEMA DE PLANTIO DIRETO
}

\begin{abstract}
A agregação do solo e a distribuição do carbono orgânico total (COT) podem ser influenciadas pelo preparo do solo e plantas de cobertura. $O$ objetivo desta pesquisa foi determinar os efeitos da rotação de culturas com plantas de cobertura na agregação do solo, a concentração de COT nas frações dos agregados do solo e a densidade do solo de solo cultivado em sistema de plantio direto (SPD) e sistema de preparo convencional do solo (PC, uma aração e duas gradagens). Este foi um estudo de três anos, com rotações entre plantas de cobertura-arroz-planta de cobertura-arroz no Cerrado brasileiro. O delineamento experimental foi de blocos casualizados, com seis tratamentos e três repetições. As plantas de cobertura (tratamentos) foram: pousio, Panicum maximum, Brachiaria ruziziensis, Brachiaria brizantha e milheto (Pennisetum glaucum). Um tratamento adicional foi incluido com pousio mais CTS como controle. As amostras de solo foram coletadas nas profundidades de 0,00-0,05 m; 0,05-0,10 m; e 0,10-0,20 m, após a segunda colheita de arroz. Os tratamentos em SPD proporcionaram maior estabilidade nos agregados do solo (variando de 86,33 a 95,37\%) do que PC, pousio arado (variando de 74,62 a 85,94\%). O PC proporcionou a maior quantidade de agregados menores que $2 \mathrm{~mm}$. As plantas de cobertura interferiram diferentemente na densidade do solo; e o tratamento milheto no SPD proporcionou os menores valores. As plantas de cobertura sem incorporação proporcionaram maior acúmulo de COT nas camadas superficiais do solo. A concentração do COT correlacionou-se positivamente com o indice de estabilidade de agregados em todas as camadas e negativamente com a densidade do solo na profundidade de 0,00-0,10 m.
\end{abstract}

Palavras-chave: Brachiaria brizantha, Brachiaria ruziziensis, sistema de plantio direto, Panicum maximum, Pennisetum glaucum, manejo do solo.

\section{INTRODUCTION}

Soil aggregation is an important factor for plant growth and directly affects water infiltration, the structure of the microbial community, soil biodiversity, soil biomass dynamics, nutrient adsorption and desorption, oxygen availability to the roots, and soil erosion (Denef et al., 2001; Franzluebbers, 2002; Six et al., 2004; Madari et al., 2005; Souza et al., 2009; An et al., 2010). Six et al. (2004) added that all of these processes greatly affect soil organic matter (SOM) dynamics and nutrient cycling. Soil aggregation is directly related to soil management practices, such as the no-till system (NTS) (Bronick and Lal, 2005). About $50 \%$ of cropped land in Brazil is under the NTS (Nascente and Crusciol, 2012). An important characteristic of the NTS is the growing of cover crops before cash crops. Calonego and Rosolem (2008) reported that cover crops increased soil aggregates because of exudates from plant roots. Water absorption by the roots causes drying of the area adjacent to the roots and promotes cohesive strength among soil particles (Garcia and Rosolem, 2010). In addition, cover crops and their residues protect soil aggregates against the impact of rainfall and variations in soil moisture and temperature (Bronick and Lal, 2005).

Residual matter from cover crops on the soil surface plus the absence of soil disturbance under the NTS reduce nutrient losses and increase soil organic matter (SOM) (Crusciol et al., 2012;
Nascente and Crusciol, 2012). The amount of SOM directly influences soil physical properties by enhancing aggregation as well as improving soil porosity, aeration, water infiltration, and water retention, which lead to a decrease in soil bulk density (Garcia and Rosolem, 2010). Traditionally, aggregate indices, such as mean weight diameter (MWD), mean geometric diameter (MGD), and the Aggregate Stability Index (ASI) have been used to assess soil aggregation (Madari et al., 2005).

There is growing interest in identifying management systems that increase SOM and soil aggregation (Pinheiro et al., 2004; Zotarelli et al., 2007, 2009). Perennial forages used as cover crops have great potential for $\mathrm{C}$ storage and directly influence SOM levels and soil aggregation (Nascente et al., 2013). There are many studies regarding soil aggregation (Castro Filho et al., 2002; Ferreira et al., 2007; Calonego and Rosolem, 2008; Canton et al., 2009; Kasper et al., 2009; An et al., 2010). However, there is little information relating soil aggregation with cover crops and crop rotations under field conditions, especially in the Cerrado region, which has two well-defined seasons, a rainy summer and dry winter (Garcia and Rosolem, 2010). We tested the hypothesis that the use of cover crops would increase the soil aggregation and SOM content with positive effects on soil bulk density. Therefore, the objective of this study was to determine the effect of cover crops on soil aggregation, $\mathrm{C}$ in soil aggregate fractions, and soil bulk density under a no-till system and conventional tillage system. 


\section{MATERIAL AND METHODS}

\section{Site description}

A field experiment was conducted in Santo Antônio de Goiás, GO, Brazil (16² $27^{\prime} \mathrm{S}, 49^{\circ} 17^{\prime} \mathrm{W}$, and $823 \mathrm{~m}$ elevation). The regional climate is tropical savanna, Aw in the Köppen classification. There are two well-defined seasons: the dry season from May to September, and a rainy season from October to April. Mean annual rainfall is $1,500 \mathrm{~mm}$, and mean annual temperature is $22.7^{\circ} \mathrm{C}$ (Silva et al., 2010). The area had natural Cerrado vegetation, to which $1 \mathrm{Mg} \mathrm{ha}^{-1}$ of lime was applied on the soil surface without tilling in 2006. It has been under the NTS for six years (2001-2007) with rotations of corn (2001, 2003, and 2005) and soybean (2002, 2004, and 2006) in the rainy season (summer), and fallow in the dry season (winter). The soil is a clay loam (kaolinitic, thermic Typic Haplorthox, a Latossolo Vermelho distrófico according to the Brazilian classification), and acidic soil in a gently undulating topography. Basic soil chemical properties were measured prior to applying treatments (Table 1). Phosphorus and $\mathrm{K}$ were extracted by Mehlich-1 extraction solution (0.05 mol L-1 $\mathrm{HC} 1$ and $0.0125 \mathrm{~mol} \mathrm{~L}^{-1} \mathrm{H}_{2} \mathrm{SO}_{4}$ ). Phosphorus was determined by colorimetry and $\mathrm{K}$ by flame photometry. Calcium, $\mathrm{Mg}$, and $\mathrm{Al}$ were extracted with $1 \mathrm{~mol} \mathrm{~L}^{-1} \mathrm{KC} 1$. Aluminum was determined by titration with $\mathrm{NaOH}$, and $\mathrm{Ca}$ and $\mathrm{Mg}$ by titration with EDTA. Micronutrients were determined by atomic absorption spectrophotometry in a portion of the extract taken for $\mathrm{P}$ determination (Claessen, 1997).

\section{Experimental design and treatments}

This was a three-year study with cover crop/rice/cover crop/rice rotations. Crops were planted in November 2007 (cover crops), November 2008 (upland rice), March 2009 (cover crops again), and November 2009 (upland rice again).

The cover crops were: fallow (spontaneous vegetation, predominantly Bidens pilosa, Commelina benghalensis, Conyza bonariensis, and Cenchrus echinatus), Panicum maximum Jacq., Brachiaria ruziziensis R. Germ. and C.M. Evrard, Brachiaria brizantha (Hochst. Ex A. Rich.) Stapf. - cultivar Marandu, and millet, Pennisetum glaucum (L.) R.
Br. - cultivar BN-2. These cover crops produced 7.42, $11.62,11.08,12.32$, and $5.14 \mathrm{Mg} \mathrm{ha}^{-1}$ of dry matter, respectively, in the average of the two growing seasons. An additional treatment was included, fallow plus conventional tillage system (CTS, one plowing and two disking) as a control. A randomized block experimental design with six treatments and three replications was used. Plot size was $6.0 \times 10 \mathrm{~m}$, with a $1-\mathrm{m}$ buffer between plots.

\section{Crop management practices}

In November 2007 and March 2009, perennial forages (B. brizantha, B. ruziziensis, and $P$. maximum) were sown in $0.20 \mathrm{~m}$ rows using a mechanical planter with a seeding rate of $3 \mathrm{~kg} \mathrm{ha}^{-1}$ (100\% germination). Millet was sown in March 2008 and 2009 , with a seeding rate of $20 \mathrm{~kg} \mathrm{ha}^{-1}$ (85\% germination) and row spacing of $0.20 \mathrm{~m}$. Cover crops were desiccated 30 days before sowing the cash crop (rice) by applying glyphosate herbicide at $1.8 \mathrm{~kg} \mathrm{ha}^{-1}$ acid equivalent with a boom sprayer at the rate of $200 \mathrm{~L} \mathrm{ha}^{-1}$. Environmental conditions during spraying were mild wind, $\sim 25^{\circ} \mathrm{C}$, and $\sim 80 \%$ relative humidity.

Rice (cultivar BRS Sertaneja) was sown on November 2008 and November 2009 at a row spacing of $0.35 \mathrm{~m}$ and 80 seeds per meter. Fertilizers applied at sowing were $20 \mathrm{~kg} \mathrm{ha}^{-1}$ of $\mathrm{N}$ as urea, $120 \mathrm{~kg} \mathrm{ha}^{-1}$ of $\mathrm{P}_{2} \mathrm{O}_{5}$ as triple super phosphate, and $60 \mathrm{~kg} \mathrm{ha}^{-1}$ of $\mathrm{K}_{2} \mathrm{O}$ as potassium chloride. Additional urea was applied at the rate of $60 \mathrm{~kg} \mathrm{ha}^{-1} \mathrm{~N}$ one day after upland rice was seeded, and $30 \mathrm{~kg} \mathrm{ha}^{-1} \mathrm{~N}$ at 45 days after rice emergence. Crop management was performed in accordance with standard practices for the rice crop.

\section{Soil sampling and analyses}

Eight undisturbed soil samples were collected in each plot at the depths of 0.00-0.05, 0.05-0.10, and $0.10-0.20 \mathrm{~m}$ in a pit $\left(1 \mathrm{~m}^{2}\right.$ area and $0.4 \mathrm{~m}$ depth $)$ after the second rice harvest (April 2010) to make a mixed soil sample for analysis of aggregate stability. In order to minimize compression, samples were taken using a bricklayer's trowel inserted into the soil at the lower level of each sampling depth. Each soil sample was passed through a $19 \mathrm{~mm}$ sieve at the sampling site by gently breaking apart the soil. Clods and aggregates larger than $19 \mathrm{~mm}$ diameter were discarded. Soil samples were air dried for $24 \mathrm{~h}$

Table 1. Basic chemical properties of the soil in the experimental area

\begin{tabular}{|c|c|c|c|c|c|c|c|c|c|c|c|}
\hline Depth & $\mathrm{pH}\left(\mathrm{H}_{2} \mathrm{O}\right)$ & $\mathrm{Ca}^{2+}$ & $\mathrm{Mg}^{2+}$ & $\mathrm{Al}^{3+}$ & $\mathbf{P}$ & $\mathbf{K}$ & $\mathbf{C u}$ & $\mathrm{Zn}$ & $\mathbf{F e}$ & Mn & SOM \\
\hline $\mathrm{m}$ & & \multicolumn{3}{|c|}{$\mathrm{cmol}_{\mathrm{c}} \mathrm{dm}^{-3}$} & \multicolumn{6}{|c|}{$\mathrm{mg} \mathrm{dm}-3$} & $\mathrm{~g} \mathrm{dm}^{-3}$ \\
\hline $0.00-0.05$ & 6.4 & 2.5 & 0.8 & 0.0 & 13.8 & 97.0 & 1.9 & 5.1 & 27.6 & 18.1 & 20.4 \\
\hline $0.05-0.10$ & 6.2 & 1.9 & 0.6 & 0.0 & 26.1 & 95.8 & 2.0 & 5.1 & 28.6 & 15.8 & 18.6 \\
\hline $0.10-0.20$ & 6.2 & 1.9 & 0.5 & 0.0 & 9.7 & 91.0 & 2.0 & 4.6 & 26.6 & 14.9 & 16.4 \\
\hline
\end{tabular}

$\mathrm{P}, \mathrm{K}$ and micronutrient: extracted by Mehlich-1 solution; $\mathrm{Ca}, \mathrm{Mg}$, and $\mathrm{Al}$ : extracted with $1 \mathrm{~mol} \mathrm{~L}^{-1} \mathrm{KCl}$; SOM: soil organic matter, after oxidation with $0.5 \mathrm{~mol} \mathrm{~L}^{-1} \mathrm{Na}_{2} \mathrm{Cr}_{2} \mathrm{O}_{7}$, and $5 \mathrm{~mol} \mathrm{~L}^{-1} \mathrm{H}_{2} \mathrm{SO}_{4}$ (Claessen, 1997). 
in shade (humidity $15 \pm 2 \%$ ). Very dry aggregates can lead to a misleadingly high resistance to breakdown and result in higher stability indices (Castro Filho et al., 2002). Air-dried soil samples were placed in plastic bags and cardboard boxes and stored at ambient temperature until analysis in the lab.

Aggregate separation methods are considered to be useful when examining certain issues of scale, but there is no standardized procedure for sampling and wet sieving (Madari et al., 2005). In our study, aggregate size classes were separated by wet sieving following a procedure based on Castro Filho et al. (1998, 2002) and Madari et al. (2005). Soil samples were sieved through $19 \mathrm{~mm}$ screen openings using a method similar to Madari et al. (2005). Air-dried soil samples were used in the fractionation of aggregate size classes according to Haynes (2000). The largest separation values by wet sieving for soils of contrasting cropping histories were obtained from air-dried samples. The soils were wet sieved through a series of eight sieves $(8,4,2,1,0.5,0.25,0.125$, and $0.053 \mathrm{~mm}$ ). In our study, sieves were selected based on Yoder (1936). The use of the $8 \mathrm{~mm}$ sieve in wet sieving was based on previous studies undertaken by Sidiras et al. (1982) and Madari et al. (2005) on a Rhodic Ferralsol from the same region under different tillage systems.

A 30 g subsample was moistened by capillarity for 5 min by placing it on a filter paper on the top of the $8 \mathrm{~mm}$ sieve. The water volume was raised inside the water tank to wet the filter paper and the soil. The filter paper was then removed and the wet sieving procedure was conducted, replicated twice for each sample. Aggregate separation was achieved by shaking the series of sieves $3.5 \mathrm{~cm}$ up and down 30 times a minute for a period of $15 \mathrm{~min}$. At the end of the 15 min cycle, the stable aggregates from each sieve were gently back-washed off the sieve into $100 \mathrm{~mL}$ glass beakers. Aggregates were oven dried $\left(60^{\circ} \mathrm{C}\right)$, weighed, and stored in plastic flasks at room temperature for $\mathrm{C}$ analysis.

The data were used to assess the state of soil aggregation. Parameters expressing the size distribution of aggregates (aggregation indices) were determined by the mean weight diameter (MWD), mean geometric diameter (MGD), and aggregate stability index (ASI) (Castro Filho et al., 1998, 2002; Madari et al., 2005).

The soil aggregation fractions were divided into three classes by size (8-19, 2-8, and 2-0.053 $\mathrm{mm})$. In each of the soil samples, aggregate size classes and total organic C (TOC) concentration were determined in finely ground samples through dry combustion with a Perkin-Elmer CHNS/O Analyser 2400.

Soil samples were collected in each treatment for all replications using the volumetric ring $\left(50 \mathrm{~cm}^{3}\right)$ (Claessen, 1997) in the 0.00-0.10 and 0.10-0.20 m layers to evaluate soil bulk density. These samples were packed separately in plastic bags and sent to the laboratory for analysis.

\section{Statistical analysis}

The analysis of variance and LSD test at $p<0.05$ were carried out using the SAS system statistical package (SAS, 1999). First, we performed an ANOVA and means test between treatments (cover crops) for each soil depth. Then, we performed another ANOVA and means test with soil depths as the source of variation (treatments) for each cover crop. Data regarding size of aggregates for analyses were divided into three classes, $8-19 \mathrm{~mm}, 2-8 \mathrm{~mm}$, and $2-0.053 \mathrm{~mm}$. Pearson correlations between total organic $\mathrm{C}$ concentrations in the whole soil and soil bulk density and the aggregation indices were determined.

\section{RESULTS AND DISCUSSION}

\section{Distribution of soil aggregates}

At the 0.00-0.05 $\mathrm{m}$ soil depth, the number of aggregates with the size of $2-0.053 \mathrm{~mm}$ was higher in the fallow plus CTS treatment $\left(60.04 \mathrm{dag} \mathrm{kg}^{-1}\right)$ than other treatments under the NTS (Table 2). Aggregates 2-8 mm size had highest values under millet (34.51 dag kg-1), which differed from $P$. maximum (17.33 dag $\mathrm{kg}^{-1}$ ) and fallow (14.68 dag kg-1). Aggregates bigger than $8 \mathrm{~mm}$ had the lowest values under the fallow plus CTS treatment (8.90 dag $\left.\mathrm{kg}^{-1}\right)$, which differed from all other treatments under the NTS.

It was also found that mean weight diameter (MWD) values under fallow $(7.591 \mathrm{~mm}), B$. brizantha $(8.619 \mathrm{~mm})$, B. ruziziensis $(7.372 \mathrm{~mm})$, and $P$. maximum $(7.617 \mathrm{~mm})$ were higher than under the fallow plus CTS treatment $(3.371 \mathrm{~mm})$. The lowest mean geometric diameter (MGD) value was under B. ruziziensis $(1.112 \mathrm{~mm})$. The lowest value of the aggregate stability index (ASI) was obtained under fallow plus CTS (74.62\%), which differed from all other treatments (Table 2 ).

At the 0.10-0.20 m depth, there was no difference among the treatments for the aggregates with the size of $2-0.053 \mathrm{~mm}$ (Table 2). Under fallow, a smaller number of $2-8 \mathrm{~mm}$ aggregates was observed (13.38 dag kg-1). As for aggregates larger than $8 \mathrm{~mm}$, the highest values were under fallow (57.52 dag kg-1). The smallest values of MWD were obtained under the $P$. maximum $(6.802 \mathrm{~mm}), B$. ruziziensis $(6.256 \mathrm{~mm})$, millet $(6.010 \mathrm{~mm})$, and fallow plus CTS $(5.752 \mathrm{~mm})$ treatments. Fallow plus CTS had the lowest values of the ASI, which differed from the $B$. brizantha treatment. 
Table 2. Effects of cover crops in rotations with rice under a no-till system on weight of soil aggregates by size class, the soil aggregation indices of mean weight diameter (MWD), mean geometric diameter (MGD), and the aggregate stability index (ASI), and soil bulk density (BD) at different soil depths

\begin{tabular}{|c|c|c|c|c|c|c|c|}
\hline \multirow{2}{*}{ Cover crop } & \multicolumn{3}{|c|}{ Aggregate by size (mm) } & \multirow{2}{*}{ MWD } & \multirow{2}{*}{ MGD } & \multirow{2}{*}{ ASI } & \multirow{2}{*}{ BD } \\
\hline & $2-0.053$ & $2-8$ & $8-19$ & & & & \\
\hline & \multicolumn{3}{|c|}{ dag $\mathrm{kg}^{-1}$} & \multicolumn{2}{|c|}{$\mathrm{mm}$} & $\%$ & $\mathrm{~kg} \mathrm{dm}^{-3}$ \\
\hline \multicolumn{8}{|c|}{$0.00-0.05 \mathrm{~m}$} \\
\hline Fallow & $37.37 \mathrm{bA}$ & $14.68 \mathrm{~b}$ & $47.95 \mathrm{aB}$ & $7.591 \mathrm{aB}$ & $1.504 \mathrm{a}$ & $86.33 \mathrm{bB}$ & $1.24 \mathrm{ab}$ \\
\hline P. maximum & $35.35 \mathrm{~b}$ & $17.33 \mathrm{~b}$ & $47.31 \mathrm{a}$ & $7.617 \mathrm{a}$ & $1.235 \mathrm{ab}$ & $92.45 \mathrm{ab}$ & $1.28 \mathrm{a}$ \\
\hline B. ruziziensis & $29.53 \mathrm{~b}$ & $28.76 \mathrm{ab}$ & $41.71 \mathrm{a}$ & $7.372 \mathrm{a}$ & $1.112 \mathrm{~b}$ & $89.43 \mathrm{ab}$ & $1.12 \mathrm{bc}$ \\
\hline B. brizantha & $26.83 \mathrm{~b}$ & $24.05 \mathrm{ab}$ & $52.90 \mathrm{a}$ & $8.619 \mathrm{a}$ & $1.129 \mathrm{ab}$ & $95.37 \mathrm{a}$ & $1.19 \mathrm{ab}$ \\
\hline Millet & $36.84 \mathrm{~b}$ & $34.51 \mathrm{a}$ & $28.65 \mathrm{~b}$ & $5.972 \mathrm{ab}$ & $1.137 \mathrm{ab}$ & $88.59 \mathrm{~b}$ & $1.00 \mathrm{cB}$ \\
\hline Fallow + CTS & $60.04 \mathrm{aA}$ & $31.06 \mathrm{abAB}$ & $8.90 \mathrm{cB}$ & $3.371 \mathrm{bB}$ & $1.214 \mathrm{abA}$ & $74.62 \mathrm{c}$ & $1.26 \mathrm{ab}$ \\
\hline CV (\%) & 18.57 & 26.21 & 23.82 & 23.46 & 17.06 & 3.91 & 6.72 \\
\hline \multicolumn{8}{|c|}{$0.05-0.10 \mathrm{~m}$} \\
\hline Fallow & $29.10 \mathrm{aAB}$ & $13.38 \mathrm{c}$ & $57.52 \mathrm{aAB}$ & $8.733 \mathrm{aAB}$ & $1.555 \mathrm{a}$ & $90.53 \mathrm{abAB}$ & $1.24 \mathrm{ab}$ \\
\hline P. maximum & $39.04 \mathrm{a}$ & $21.51 \mathrm{bc}$ & $39.45 \mathrm{bc}$ & $6.802 \mathrm{~b}$ & $1.229 \mathrm{a}$ & $90.45 \mathrm{ab}$ & $1.28 \mathrm{a}$ \\
\hline B. ruziziensis & $35.07 \mathrm{a}$ & $36.25 \mathrm{a}$ & $30.25 \mathrm{c}$ & $6.256 \mathrm{~b}$ & $1.125 \mathrm{a}$ & $90.07 \mathrm{ab}$ & $1.12 \mathrm{bc}$ \\
\hline B. brizantha & $31.26 \mathrm{a}$ & $31.46 \mathrm{ab}$ & $48.12 \mathrm{ab}$ & $8.390 \mathrm{a}$ & $1.071 \mathrm{a}$ & $94.19 \mathrm{a}$ & $1.19 \mathrm{ab}$ \\
\hline Millet & $38.72 \mathrm{a}$ & $31.29 \mathrm{ab}$ & $29.98 \mathrm{cA}$ & $6.010 \mathrm{bA}$ & $1.173 \mathrm{aA}$ & $89.60 \mathrm{ab}$ & $1.00 \mathrm{cB}$ \\
\hline Fallow + CTS & $42.33 \mathrm{aB}$ & $29.04 \mathrm{abB}$ & $28.64 \mathrm{c}$ & $5.752 \mathrm{~b}$ & $1.176 \mathrm{a}$ & $85.94 \mathrm{~b}$ & $1.26 \mathrm{ab}$ \\
\hline CV (\%) & 15.41 & 27.62 & 21.13 & 10.60 & 21.83 & 3.51 & 6.72 \\
\hline \multicolumn{8}{|c|}{$0.10-0.20 \mathrm{~m}$} \\
\hline Fallow & $22.42 \mathrm{bB}$ & $16.28 \mathrm{c}$ & $61.30 \mathrm{aA}$ & $9.320 \mathrm{a}$ & $1.532 \mathrm{a}$ & $93.44 \mathrm{aA}$ & $1.34 \mathrm{a}$ \\
\hline P. maximum & $31.92 \mathrm{ab}$ & $23.26 \mathrm{bc}$ & $44.82 \mathrm{ab}$ & $7.541 \mathrm{abc}$ & $1.181 \mathrm{a}$ & $92.55 \mathrm{a}$ & $1.29 \mathrm{ab}$ \\
\hline B. ruziziensis & $25.27 \mathrm{ab}$ & $40.35 \mathrm{a}$ & $34.39 \mathrm{bc}$ & $6.919 \mathrm{bc}$ & $1.055 \mathrm{a}$ & $91.67 \mathrm{ab}$ & $1.20 \mathrm{bc}$ \\
\hline B. brizantha & $25.08 \mathrm{ab}$ & $26.55 \mathrm{~b}$ & $48.36 \mathrm{ab}$ & $8.114 \mathrm{ab}$ & $1.120 \mathrm{a}$ & $93.77 \mathrm{a}$ & $1.13 \mathrm{c}$ \\
\hline Millet & $28.88 \mathrm{ab}$ & $31.07 \mathrm{ab}$ & $40.05 \mathrm{bc}$ & $7.257 \mathrm{abc}$ & $1.136 \mathrm{a}$ & $94.49 \mathrm{a}$ & $1.11 \mathrm{cA}$ \\
\hline Fallow + CTS & $38.50 \mathrm{aB}$ & $39.18 \mathrm{aA}$ & $22.31 \mathrm{cA}$ & $5.367 \mathrm{cA}$ & $1.039 \mathrm{aB}$ & $77.95 \mathrm{~b}$ & $1.36 \mathrm{a}$ \\
\hline CV (\%) & 25.53 & 17.99 & 28.52 & 16.22 & 23.44 & 8.74 & 5.85 \\
\hline
\end{tabular}

Means followed by the same lowercase letter in columns did not differ by the LSD test at $p<0.05$. Means followed by uppercase letters compare the same cover crop at different soil layers (0.00-0.05, 0.05-0.10, and 0.10-0.20 m) when significant by the LSD test at $\mathrm{p}<0.05$. CV: coefficient of variation.

In the soil depth of $0.10-0.20 \mathrm{~m}$, fallow plus CTS showed the highest values of $2-0.053 \mathrm{~mm}$ aggregates (38.50 dag $\mathrm{kg}^{-1}$, which differed from the fallow treatment $\left(22.42 \mathrm{dag} \mathrm{kg}^{-1}\right)$ under the NTS (Table 2). In contrast, fallow plus CTS exhibited the smaller values of aggregates bigger than $8 \mathrm{~mm}$ (5.367 dag $\mathrm{kg}^{-1}$ ) and differed from the fallow treatment in the NTS (61.30 dag kg-1). Fallow plus CTS also exhibited the lowest values of MWD and the ASI.

According to Lovato et al. (2004) and Bayer et al. (2000), high root density produced by grasses provided exudates to the soil and significantly affected soil structure and improved microbial activity, and this also plays a fundamental role in soil aggregation. Souza et al. (2009) reported that the vigorous root system of perennial forages contributed to the formation of aggregates and to improving soil physical properties, which could be observed in the aggregates larger than $8 \mathrm{~mm}$ under the fallow, $P$. maximum, B. ruziziensis, and $B$. brizantha treatments, especially at the soil depth of 0.00-0.05 m (Table 2).

The higher rates of soil aggregation observed under fallow may be due to the diversity of plant species with different shapes and sizes of the root system, which provided greater stability to the aggregates. However, fallow increased the weed population for the cash crops that followed (Nascente et al., 2004).

Almost all treatments with cover crops in the NTS had similar values for aggregate size in all the soil layers evaluated (Table 2). In contrast, the CTS treatment exhibited the greatest number of aggregates less than $2 \mathrm{~mm}$ and the lowest number of aggregates higher than $8 \mathrm{~mm}$ in all soil depths, especially in the $0.00-0.05 \mathrm{~m}$ soil 
layer. Typically, conventional tillage leads to the destruction of macroaggregates, increasing the number of microaggregates in the soil (Bronick and Lal, 2005; Ferreira et al., 2007). Thus, it appears that soil management without tillage and with the use of cover crops favored an increase in the number of macroaggregates, which may be due to the growth of these plants (especially during winter) as they release their root exudates in the soil medium, developing links among soil mineral particles, favoring the formation and stabilization of aggregates in the A horizon (Bronick and Lal, 2005; Ferreira et al., 2007). According to Kasper et al. (2009), tillage in general inhibits the development of larger stable aggregates.

It is important to note that regardless of the soil management system (NTS or CTS), the aggregate stability indices were high (above $74 \%$ ) in all treatments (Table 2) and at all depths, indicating good soil structure. According to Lal (2000), tropical soils (Oxisols) generally have high aggregate stability. Madari et al. (2005) adds that the size distribution of water stable aggregates in these soils can be large. However, it is important to manage the soil properly to preserve its good structure and to avoid possible problems with erosion. Under the NTS, cover crops and straws act as agents of formation and stabilization of aggregates (Six et al., 2002; Calonego and Rosolem, 2008; Kasper et al., 2009). Zotarelli et al. (2007), Calonego and Rosolem (2008) and Garcia and Rosolem (2010) observed that the NTS had a higher percentage of soil aggregate stability in water compared to management systems that disturb the soil.

\section{Soil bulk density}

Soil bulk density (BD) was lower under millet at all the soil depths evaluated (Table 2). Therefore, millet has great potential for reducing soil BD. Similarly, Gonçalves et al. (2006) and Bordin et al. (2008) reported that millet promoted soil aeration. Millet as a cover crop has great potential for reducing soil $\mathrm{BD}$, due to its root growth, and for increasing organic matter content in the soil profile (Castro Filho et al., 2002; Gonçalves et al., 2006; Silveira Neto et al., 2006; Calonego and Rosolem, 2008).

Under the millet treatment, the surface soil (0.00-0.10 m) had lower density compared to soil from the 0.10-0.20 m layer (Table 2). This may be caused by accumulation of plant residues on the soil surface from cover crops under the NTS. The high density of roots in the surface soil may also have contributed to lower soil density. The biopores produced from dead roots are important factors for low soil density and they also improve oxygen diffusion, gas exchange, and water infiltration (Calonego and Rosolem, 2008). The use of cover crops for breaking up compacted layers instead of using mechanical disruption (tillage) has been reported in several studies (Gonçalves et al., 2006; Calonego and Rosolem, 2008).

Soil BD was found to be negatively correlated with TOC at the 0.00-0.10 m depth (Figure 1). This could be because SOM directly affects soil aggregation and macroporosity by the density of organic matter itself or through the effect of increasing the biological activity of the soil (Franzluebbers, 2002). Similar results were obtained by Stone and Silveira (2001) and Silveira Neto et al. (2006), who observed that soil BD decreased under the NTS through an increase in organic matter in the surface layer.

\section{Total organic carbon in fractions of aggregates}

The concentration of total organic carbon (TOC) in the aggregate fractions smaller than $2 \mathrm{~mm}$ was highest under $P$. maximum and millet at the 0.00-0.05 m depth. However, in the 0.05-0.10 $\mathrm{m}$ depth, there was no difference between treatments in this fraction size, whereas in the 0.10-0.20 m depth, fallow plus CTS had the lowest value (Table 3). Fallow plus CTS had the lowest TOC in the aggregate fractions greater than $8 \mathrm{~mm}$ in the 0.00-0.05 m layer.

The amount of TOC was higher in the soil surface than in the deeper layers for aggregates smaller than $2 \mathrm{~mm}$ ( $P$. maximum and millet) (Table 3). This may have happened because of the use of cover crops without tillage. Sisti et al. (2004), Diekow et al. (2005), Madari et al. (2005), Siqueira Neto et al. (2009), Zotarelli et al. (2009), and Figueiredo et al. (2010) also reported accumulation of organic matter on the soil surface in a clay loam Rhodic Ferralsol.

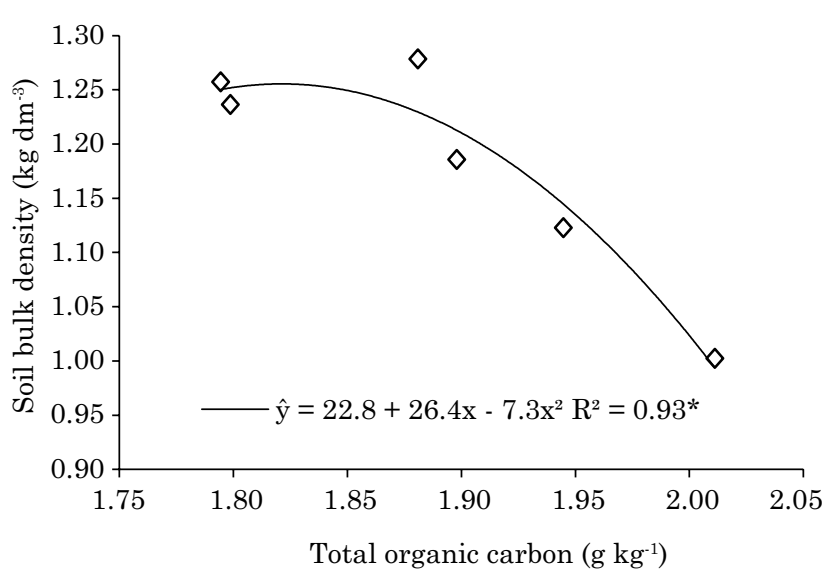

Figure 1. Relationship between soil bulk density and concentration of total organic carbon throughout the soil at the depth of 0.00-0.10 m. The diamond symbol means the average of soil bulk density for the respective total organic carbon in each cover crop treatment. 
Table 3. Concentration of total organic carbon in the fraction of soil aggregates as affected by cover crops in rotation with rice under a no-till system at each soil depth $(0.00-0.05,0.05-0.10$, and $0.10-0.20 \mathrm{~m}$ )

\begin{tabular}{|c|c|c|c|}
\hline \multirow{2}{*}{ Cover crop } & \multicolumn{3}{|c|}{ Aggregate by size class } \\
\hline & $2-0.053 \mathrm{~mm}$ & $2-8 \mathrm{~mm}$ & $8-19 \mathrm{~mm}$ \\
\hline & \multicolumn{3}{|c|}{$\mathrm{g} \mathrm{kg}^{-1}$} \\
\hline & \multicolumn{3}{|c|}{$0.00-0.05 \mathrm{~m}$} \\
\hline Fallow & $8.44 \mathrm{bc}$ & $3.62 \mathrm{aA}$ & $2.03 \mathrm{ab}$ \\
\hline Panicum maximum & $9.25 \mathrm{aA}$ & $3.69 \mathrm{aA}$ & $1.84 \mathrm{ab}$ \\
\hline Brachiaria ruziziensis & $8.80 \mathrm{ab}$ & $4.32 \mathrm{aA}$ & $1.83 \mathrm{ab}$ \\
\hline Brachiaria brizantha & $7.88 \mathrm{c}$ & $3.62 \mathrm{aA}$ & $1.85 \mathrm{abA}$ \\
\hline Millet & $9.32 \mathrm{aA}$ & $4.05 \mathrm{a}$ & $2.34 \mathrm{aA}$ \\
\hline Fallow + CTS & $6.21 \mathrm{~dB}$ & $3.62 \mathrm{aA}$ & $1.76 \mathrm{~b}$ \\
\hline \multirow{2}{*}{ CV (\%) } & 14.43 & 10.24 & 4.90 \\
\hline & \multicolumn{3}{|c|}{$0.05-0.10 \mathrm{~m}$} \\
\hline Fallow & $8.60 \mathrm{a}$ & $3.43 \mathrm{abA}$ & $1.90 \mathrm{a}$ \\
\hline Panicum maximum & $850 \mathrm{aB}$ & $3.34 \mathrm{abAB}$ & $1.68 \mathrm{a}$ \\
\hline Brachiaria ruziziensis & $8.16 \mathrm{a}$ & $3.58 \mathrm{abB}$ & $1.90 \mathrm{a}$ \\
\hline Brachiaria brizantha & $7.44 \mathrm{a}$ & $3.18 \mathrm{abAB}$ & $1.61 \mathrm{aAB}$ \\
\hline Millet & $8.47 \mathrm{aB}$ & $3.76 \mathrm{a}$ & $1.90 \mathrm{aB}$ \\
\hline Fallow + CTS & $8.39 \mathrm{aA}$ & $3.03 \mathrm{bC}$ & $1.76 \mathrm{a}$ \\
\hline \multirow[t]{2}{*}{ CV (\%) } & 10.25 & 13.82 & 8.30 \\
\hline & \multicolumn{3}{|c|}{$0.10-0.20 \mathrm{~m}$} \\
\hline Fallow & $7.79 \mathrm{a}$ & $2.92 \mathrm{cdB}$ & $1.54 \mathrm{c}$ \\
\hline Panicum maximum & $8.05 \mathrm{aB}$ & $3.04 \mathrm{cdB}$ & $1.53 \mathrm{c}$ \\
\hline Brachiaria ruziziensis & $8.34 \mathrm{a}$ & $3.46 \mathrm{abB}$ & $1.66 \mathrm{bc}$ \\
\hline Brachiaria brizantha & $7.46 \mathrm{ab}$ & $2.84 \mathrm{~dB}$ & $1.26 \mathrm{~dB}$ \\
\hline Millet & $8.27 \mathrm{aB}$ & $3.76 \mathrm{a}$ & $1.75 \mathrm{abB}$ \\
\hline Fallow + CTS & $6.42 \mathrm{bB}$ & $3.32 \mathrm{bcB}$ & $1.90 \mathrm{a}$ \\
\hline CV (\%) & 6.40 & 7.18 & 7.16 \\
\hline
\end{tabular}

Means followed by the same lowercase letter in columns did not differ by the LSD test at $p<0.05$. Means followed by uppercase letters compare the same cover crop at different soil layers (0.00-0.05, 0.05-0.10, and 0.10-0.20 m) when significant by the LSD test at $p<0.05$. CV: coefficient of variation.

Table 4. Pearson correlation between the total organic carbon concentration throughout the soil and the soil aggregation indices MWD (mean weight diameter), MGD (mean geometric diameter), and ASI (aggregate stability index) at different soil depths (0.00-0.05, 0.05-0.10, and 0.10-0.20 m)

\begin{tabular}{|c|c|c|c|}
\hline \multirow{2}{*}{ Depth } & \multicolumn{3}{|c|}{ Indice } \\
\hline & MWD & MGD & ASI \\
\hline \multicolumn{4}{|l|}{$\mathrm{m}$} \\
\hline $0.00-0.05$ & $0.63^{* *}$ & $14.39^{\mathrm{ns}}$ & $0.58^{* *}$ \\
\hline $0.05-0.10$ & $8.27^{\mathrm{ns}}$ & $21.48^{\mathrm{ns}}$ & $0.47^{*}$ \\
\hline $0.10-0.20$ & $9.14^{\mathrm{ns}}$ & $0.51^{*}$ & $0.40^{*}$ \\
\hline
\end{tabular}

\section{Correlation between total organic carbon and soil fraction with soil aggregation indices}

The correlations between the TOC and the index of soil aggregation ASI were highly significant $(r=0.58)$ for the 0.00-0.05 m layer and significant for both the $0.05-0.10 \mathrm{~m}(\mathrm{r}=0.47)$ and $0.10-0.20 \mathrm{~m}(\mathrm{r}=0.40)$ layers (Table 4). Concentrations of TOC were also highly correlated with MWD in the 0.00-0.05 m layer $(\mathrm{r}=0.63)$ and with MGD in the 0.10-0.20 m layer $(r=0.51)$. Therefore, increasing soil organic $\mathrm{C}$ often leads to better soil aggregation. Similar results were reported by other authors for the tropical regions (Six et al., 1999; Madari et al., 2005; Salton et al., 2008; Veiga et al., 2009; Souza et al., 2009; Garcia and Rosolem, 2010). In addition, Six et al. (1999) showed that due to the increase in organic matter, smaller aggregates coalesce into larger aggregates, improving soil structure. Zotarelli et al. (2007) reported that soils in the NTS had a higher number of aggregates. Vasconcelos et al. (2010) adds that stabilization of aggregates is directly related to organic matter content, mainly in the surface layer, and that as the amount of organic matter decreases due to conventional tillage or low input of plant biomass, a reduction in the stability of soil aggregates usually occurs.

\section{CONCLUSIONS}

The no-tillage system provided for greater stability of soil aggregates (ranging from 86.33 to $95.37 \%$ ) compared to the fallow plus CTS (ranging from 74.62 to $85.94 \%$ );

The fallow plus CTS treatment exhibited the highest number of aggregates smaller than $2 \mathrm{~mm}$, which indicates that tilling the soil broke up the soil aggregates;

Cover crops significantly affected soil bulk density, and the lowest soil densities were found in the millet treatments in the no-tillage system;

Cover crops without tillage led to the greater accumulation of total organic carbon in the surface layers of the soil;

Total organic carbon positively correlated with the aggregate stability index at all depths and the total organic carbon concentration correlated negatively with soil bulk density.

\section{ACKNOWLEDGMENTS}

Our thanks to Embrapa (Brazilian Agricultural Research Corporation) for supporting this research and for providing a PhD. scholarship to the first author, and to the CNPq (National Council of 
Scientific and Technological Development) for a research excellence award to the second and third authors. And to Dr. Beata Emoke Madari for help in soil analyses.

\section{REFERENCES}

An S, Mentler A, Mayer H, Blum WEH. Soil aggregation, aggregate stability, organic carbon and nitrogen in different soil aggregate fractions under forest and shrub vegetation on the Loess Plateau, China. Catena. 2010;81:226-33.

Bayer C, Mielniczuk J, Amado TJC, Martin-Neto L, Fernandes SV. Organic matter storage in a sandy clay loam Acrisol affected by tillage and cropping systems in southern Brazil. Soil Till Res. 2000;54:101-9.

Bordin I, Neves CSVJ, Francio Filho P, Preti EA, Cardoso C. Crescimento de milheto e guandu, desempenho de plantas cítricas e propriedades físicas do solo escarificado em um pomar. $\mathrm{R}$ Bras Ci Solo. 2008;32:1409-18.

Bronick CJ, Lal R. Soil structure and management: A review. Geoderma. 2005;124:3-22.

Calonego JC, Rosolem CA. Soil aggregate stability after management with crop rotation and chiseling. $\mathrm{R}$ Bras Ci Solo. 2008;32:1399-407.

Canton Y, Sole-Benet A, Asensio C, Chamizo S, Puigdefabregas J. Aggregate stability in range sandy loam soils. Relationships with runoff and erosion. Catena. 2009;77:192-9.

Castro Filho C, Lourenço A, Guimarães MF, Fonseca ICB. Aggregate stability under different soil management systems in a Red Latosol in the state of Paraná, Brazil. Soil Till Res. 2002;65:45-51.

Castro Filho C, Muzilli O, Podanoschi AL. Estabilidade dos agregados e sua relação com o teor de carbono orgânico num Latossolo Roxo distrófico, em função de sistemas de plantio, rotações de culturas e métodos de preparo de amostras. $\mathrm{R}$ Bras Ci Solo. 1998;22:527-38.

Claessen MEC, organizador. Manual de métodos de análise de solo. $2^{a}$ ed. Rio de Janeiro: Empresa Brasileira de Pesquisa Agropecuária; 1997.

Crusciol CAC, Mateus GP, Nascente AS, Martins PO, Borghi E, Pariz CM. An innovative crop-forage intercrop system: early cycle soybean cultivars and palisadegrass. Agron J. 2012;104:1085-95.

Denef K, Six J, Bossuyt H, Frey SD, Elliott ET, Merckx R, Paustian K. Influence of dry-wet cycles on the interrelationship between aggregate, particulate organic matter, and microbial community dynamics. Soil Biol Biochem. 2001;33:1599-611.

Diekow J, Mielniczuk J, Knicker H, Bayer C, Dick DP, Kogel-Knabner I. Soil $\mathrm{C}$ and $\mathrm{N}$ stocks as affected by cropping systems and nitrogen fertilization in a southern Brazil Acrisol managed under no-tillage for 17 years. Soil Till Res. 2005;81:87-95.

Ferreira FP, Azevedo AC, Dalmolin RSD, Girelli D. Organic carbon, iron oxides and aggregate distribution in two basaltic soils from Rio Grande do Sul State - Brasil. Ci Rural. 2007;37:381-8.

Figueiredo CC, Resck DVS, Carneiro MAC. Labile and stable fractions of soil organic matter under management systems and native cerrado. R Bras Ci Solo. 2010;34:907-16.
Franzluebbers AJ. Soil organic matter stratification ratio as an indicator of soil quality. Soil Till Res. 2002;66:95-106.

Garcia RA, Rosolem CA. Aggregates in a Rhodic Ferralsol under no-tillage and crop rotation. Pesq Agropec Bras. 2010;45:1489-98.

Gonçalves WG, Jimenez RL, Araujo Filho JV, Assis RL, Silva GP, Pires FR. Root system of cover crops under soil compaction. Eng Agric. 2006;26:67-75.

Haynes RJ. Interactions between soil organic matter status, cropping history, method of quantification and sample pretreatment and their effects on measured aggregate stability. Biol Fertil Soils. 2000;30:270-5.

Kasper M, Buchan GD, Mentler A, Blum WEH. Influence of soil tillage systems on aggregate stability and the distribution of $\mathrm{C}$ and $\mathrm{N}$ in different aggregate fractions. Soil Till Res. 2009;105:192-9.

Lal R. Physical management of soils of the tropics: priorities for the $21^{\text {st }}$ century. Soil Sci. 2000;165:165-91.

Lovato T, Mielniczuk J, Bayer C, Vezzani C. Adição de carbono e nitrogênio e sua relação com os estoques no solo e com o rendimento do milho em sistemas de manejo. $\mathrm{R}$ Bras $\mathrm{Ci}$ Solo. 2004;28:175-87.

Madari BE, Machado PLOA, Torres E, Andrade AG, Valencia LIO. No tillage and crop rotation effects on soil aggregation and organic carbon in a Rhodic Ferralsol from southern Brazil. Soil Till Res. 2005;80:185-200.

Nascente AS, Crusciol CAC. Cover crops and herbicide timing management on soybean yield under no-tillage system. Pesq Agropec Bras. 2012;47:187-92.

Nascente AS, Li YC, Crusciol CAC. Cover crops and no-till effects on physical fractions of soil organic matter. Soil. Till Res. 2013;130:52-7.

Nascente AS, Pereira W, Medeiros MA. Weed interference in processing tomato crops. Hortic Bras. 2004;22:602-6.

Pinheiro EFM, Pereira MG, Anjos LHC, Machado PLOA. Densimetric fractionation of organic matter in soil under different tillage and vegetation cover in Paty do Alferes, State of Rio de Janeiro (Brazil). R Bras Ci Solo. 2004;28:731-7.

Salton JC, Mielniczuk J, Bayer C, Boeni M, Conceição PC, Fabrício AC, Macedo MCM, Broch DL. Soil aggregation and aggregate stability under crop-pasture systems in Mato Grosso do Sul State, Brazil. R Bras Ci Solo. 2008;32:11-21.

Statistics Analyses Systems - SAS. Procedure guide for personal computers: Version 5. Cary, NC: Statistics Analyses Systems Institute; 1999.

Sidiras N, Henklain JC, Derpsch R. Comparison of three different tillage systems with respect to aggregate stability, the soil and water conservation and the yields of soybean and wheat on an Oxisol. J Agron Crop Sci. 1982;151:137-48.

Silva SC, Heinemann AB, Paz RLF, Amorim AO. Informações meteorológicas para pesquisa e planejamento agrícola, referentes ao ano de 2009, do município de Santo Antônio de Goiás, GO. Santo Antônio de Goiás: Empresa Brasileira de Pesquisa Agropecuária; 2010.

Silveira Neto AN, Silveira PM, Stone LF, Oliveira LFC. Effects of soil tillage and crop rotation systems on soil physical attributes. Pesq Agropec Trop. 2006;36:1-20. 
Siqueira Neto M, Venzke Filho SP, Piccolo MC, Cerri CEP, Cerri CC. Crop rotation under no-tillage in Tibagi (Parana State, Brazil). I - Soil carbon sequestration. R Bras Ci Solo. 2009;33:1013-22.

Sisti CPJ, Santos HP, Kohhann R, Alves BJR, Urquiaga S, Boddey RM. Change in carbon and nitrogen stocks in soil under 13 years of conventional or zero tillage in southern Brazil. Soil Till Res. 2004;76:39-58.

Six J, Bossuyt H, De Gryze S, Denef K. A history of research on the link between (micro) aggregates, soil biota, and soil organic matter dynamics. Soil Till Res. 2004;79:7-31.

Six J, Callewaert P, Lenders S, De Gryze S, Morris SJ, Gregorich EG, Paul EA, Paustian K. Measuring and understanding carbon storage in afforested soils by physical fractionation. Soil Sci Soc Am J. 2002;66:1981-7.

Six J, Elliot ET, Paustain K. Aggregate and soil organic matter dynamics under conventional and no-tillage system. Soil Sci Soc Am J. 1999;63:1350-8.

Souza ED, Costa SEVGA, Anghinoni I, Carvalho PCF, Andrigheti $\mathrm{MH}$, Cao EG. Soil organic carbon and nitrogen stocks in an untilled crop-livestock system under different grazing intensities. R Bras Ci Solo. 2009;33:1829-36.

Stone LF, Silveira PM. Effects of tillage and crop rotation on soil porosity and density. R Bras Ci Solo. 2001;25:395-401.

Vasconcelos RFB, Cantalice JRB, Oliveira VS, Costa YDJ, Cavalcante DM. Aggregate stability in a dystrophic cohesive Yellow Latosol of a coastal plain under different sugarcane residue application. R Bras Ci Solo. 2010;34:309-16.

Veiga M, Reinert DJ, Reichert JM. Aggregate stability as affected by short and long term-tillage systems and nutrient sources of a Hapludox in Southern Brazil. R Bras Ci Solo. 2009;33:766-77.

Yoder RE. A direct method of aggregate analysis of soils and a study of the physical nature of erosion losses. J Am Soc Agron. 1936;28:337-51.

Zotarelli L, Avila L, Scholberg JMS, Alves BJR. Benefits of vetch and rye cover crops to sweet corn under no-tillage, Agron J. 2009;101:252-60.

Zotarelli L, Alves BJR, Urquiaga S, Boddey RM, Six J. Impact of tillage and crop rotation on light fraction and intra-aggregate soil organic matter in two Oxisols. Soil Till Res. 2007;95:196-206. 